\title{
Topographical study of albino nasal cancer in a developing community
}

\begin{abstract}
An outstanding feature of skin cancer is its selection of the albino for attack in the tropics. In particular, the topographic selection has been of considerable interest. What stands out in the publications is the generalization that the face is the choice site for attack. Therefore, this paper draws attention to the nose with special reference to the Ibo ethnic group in Nigeria.
\end{abstract}

Keywords: Skin, albinism, tropics, cancer, nose, Nigerian Ibos
Volume 9 Issue 6 - 2018

Wilson IB Onuigbo

Department of Pathology, Nigeria

Correspondence: Wilson IB Onuigbo, Department of Pathology, Medical Foundation and Clinic, 8 Nsukka Lane, Enugu 4000।, Nigeria, Email wilson.onujgbo@gmail.com

Received: July 31, 2018 | Published: December II, 2018

\section{Introduction}

The research group from Kenya asserted that "Albinos in Africa are at constant risk of developing skin cancer due to damage caused by ultra-violet exposure". ${ }^{1}$ This was put as "Albino is an established risk factor for skin cancer in Black Africans" by Nigerian authors. ${ }^{2}$ What stands out is the generalization that the head and neck are the most frequent sites afflicted in Tanzania, ${ }^{3,4}$ and Nigeria. ${ }^{5,6}$ Therefore, this paper draws attention to the nose whose topography is deemed to be worthy of documentation.

\section{Investigation}

Birmingham (UK) authors hypothesized that the establishment of a histopathology data pool facilitates epidemiological analysis. ${ }^{7}$ Now, such a pool was established at Enugu, erstwhile capital of Eastern Nigeria, to serve the Ibo ethnic group. ${ }^{8}$ As the pioneer pathologist, I encouraged the sending of specimens provided that the HISTOLOGY REQUEST FORM contained epidemiological details. Moreover, since I retained a copy of the results, analysis was facilitated. Let me do so in Tabular Form.

\section{Results and discussion}

Previous works on malignancy in the albinos in this community varied. Firstly, no albino should suffer from extensive skin cancer let alone die there-from. ${ }^{9}$ Secondly, albinism cancer requires worldwide epidemiological research. ${ }^{10}$ Thirdly, the recurrent form of albino cancer should be recognized. ${ }^{11}$ Fourthly, albino cancer will end if a community's cancer surveillance program is successful. ${ }^{12}$ Fifthly, there is its adenoid cystic carcinoma variant. ${ }^{13}$ Finally, the illness will end if what happened in the case of chimney sweeper's cancer in Britain, namely, the government's regulation stopping the employments of boys. ${ }^{14}$ Here, it will be achieved through compulsory employment indoors! Regarding histological classification, there is more to it than the squamous cell variety. A good example was the albino that had on one slide from the face as many as the squamous, the basal celled and the adenoid cystic variety. ${ }^{15}$

Table I Epidemiological data on albino nasal cancer

\section{Conclusion}

\begin{tabular}{llllllll}
\hline No & Initials & Age & Sex & Doctor & Site & Cm & Carcinoma \\
\hline 1 & NP & 37 & F & Onah & Alae nasi & 3 & Adenoid cystic \\
2 & OC & 30 & F & Achebe & Alae nasi & 4 & Squamous \\
3 & ON & 40 & M & Obadike & Dorsum & 1 & Basisquamous \\
4 & OA & 29 & F & Achebe & Nasolabial & 3 & Squamous \\
5 & EO & 43 & M & Achebe & Alae nasi & 4 & Adenoid cystic \\
6 & OO & 46 & M & Achebe & Anterior & 6 & Basal cell \\
7 & EO & 20 & M & Iregbulem & Vertex & 3 & Basosquamous \\
8 & UG & 50 & F & Nnabuko & Alae nasi & 3 & Squamous \\
\hline
\end{tabular}

In consonance with the above case, the lesions in this cohort included also adenoid cystic carcinoma and basis squamous carcinoma. Moreover, owing to the clinicians being mandated to be observant in their Request Forms, the topographical assessments included mostly the alae nasi with the dorsum, anterior part and vertex.

\section{Acknowledgments}

None.

\section{Conflicts of interest}

Author declares that there is no conflict of interest.

\section{References}

1. Emadi SE, Suleh AJ, Babamahmoodi F, et al. Common malignant cutaneous conditions among albinos in Kenya. Med $J$ Islam Repub Iran. 2017;31:3.

2. Asuquo ME, Ngim O, Ebughe G, et al. Skin cancers amongst four Nigerian albinos. Int J Dermatol. 2009;48(6):636-638.

3. Mabula JB, Chalya PL, Mchembe MD, et al. Skin cancers among albinos at a University teaching hospital in Northwestern Tanzania: A retrospective review of 64 cases. BMC Dermatol. 2012;12:5.

4. Kiprono SK, Chaula BM, Beltraminelli H. Histological review of skin cancers in African albinos: A 10year retrospective review. BMC Cancer. 2014;14:157. 
5. Yakubu A, Mabogunje OA. Skin cancer in African albinos. Acta Oncologica. 1993;32(6):621-622.

6. Asuquo ME, Otei OO, Omotoso J, et al. Skin cancer in albinos at the University of Calabar Teaching Hospital, Calabar, Nigeria. Dermatol Online J. 2010;16(4):14.

7. Macartney JC, Rollaston TP, Codling BW. Use of a histopathology data pool for epidemiological analysis. J Clin Pathol. 1980;33(4):351-353.

8. Basden GT. Niger Ibos. London: Cass; 1966.

9. Onuigbo WIB. No albino should suffer from extensive skin cancer let alone die there-from. J Cancer Prev Curr Res. 2015;2(3):00040.

10. Onuigbo WIB. Albinism cancer requires worldwide epidemiological research. J Pigment Disord. 2015;2(8):1000201.
11. Onuigbo WIB. The recognition of a recurrent form of albino skin cancer. Arch Can Res. 2016;4:3.

12. Onuigbo WIB. Albino skin cancer will end if a community's cancer surveillance program is successful. J Health Edn Res Dev. 2016;4:161.

13. Onuigbo WIB. Adenocystic carcinoma as a molecular variant of albino skin cancer. J Med Diag Methods. 2016;5:1.

14. Onuigbo WIB. The influence of Pott's irritation theory of occupational cancer during the 19th Century: A review with hypothesis on albinism sunlight induced cancer. J Cancer Prev Curr Res. 2015;2(5):00054.

15. Onuigbo WIB, Nnabuko RE. Three different carcinomas clustered in one facial focus in albino. Nig J Surg Sci. 2009;19:38-40. 